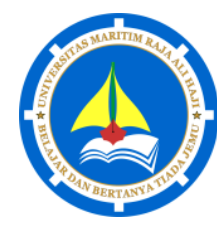

Jurnal Anugerah, 1(2) (2019)
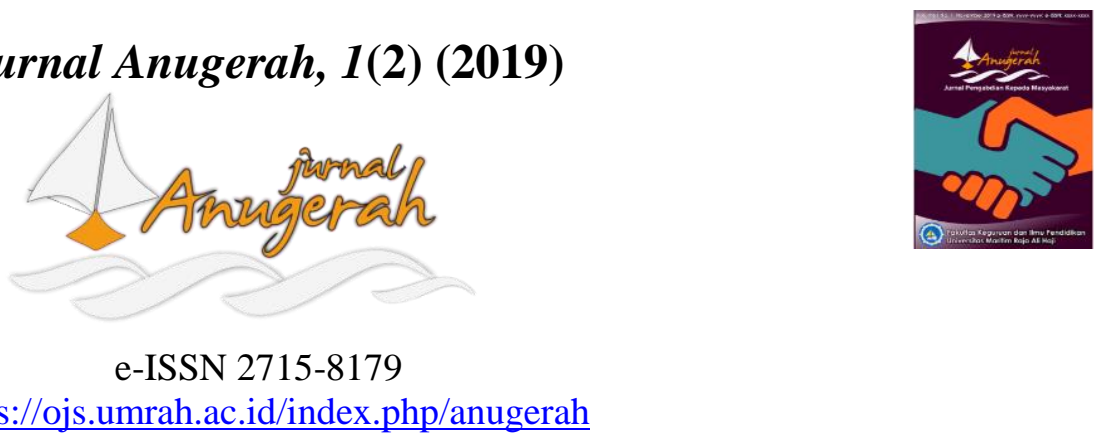

https://ojs.umrah.ac.id/index.php/anugerah

\title{
Pengenalan Pendekatan STEM sebagai Inovasi Pembelajaran Era Revolusi Industri 4.0
}

\author{
Nur Izzati ${ }^{1 *}$, Linda Rosmery T. ${ }^{2}$, Susanti ${ }^{3}$, Nur Asma Riani Siregar ${ }^{4}$ \\ 1, 2, 3, 4 Universitas Maritim Raja Ali Haji, Tanjungpinang, Provinsi Kepulauan Riau 29115, Indonesia \\ e-mail: *nurizzati@umrah.ac.id
}

Pengiriman: 1 Desember 2019; Diterima: 23 Desember 2019; Publikasi: 30 Desember 2019

DOI: https://doi.org/10.31629/anugerah.v1i2.1776

\begin{abstract}
Abstrak
Pada era revolusi industri 4.0, guru dituntut untuk mampu melaksanakan pembelajaran yang kreatif dan inovatif dengan memanfaatkan teknologi. Salah satu pendekatan pembelajaran yang sesuai dengan tuntutan tersebut adalah pendekatan STEM (Science, Technology, Engineering and Mathematics). Namun, pendekatan ini masih terbilang asing bagi kebanyakan guru maupun mahasiswa calon guru di Provinsi Kepulauan Riau. Kegiatan pengabdian yang bertujuan untuk memperkenalkan pendekatan STEM kepada masyarakat di Provinsi Kepulauan Riau ini diikuti oleh 120 orang peserta yang terdiri dari guru SMA sebagai sasaran utama, mahasiswa calon guru serta siswa SMA. Kegiatan pengenalan ini diawali dengan pemaparan materi pendekatan STEM, dilanjutkan dengan sesi diskusi dan tanya jawab serta diakhiri dengan evaluasi pelaksanaan kegiatan melalui pengisian angket. Hasil evaluasi kegiatan tersebut menunjukkan bahwa 93,75\% peserta menyatakan topik yang disajikan menarik dan menggugah rasa ingin tahu peserta, sehingga terjadi penambahan wawasan dan pengetahuan peserta tentang pendekatan STEM.
\end{abstract}

Kata kunci: STEM; revolusi industri 4.0

\begin{abstract}
In the Industrial Revolution Era 4.0, teachers were required to be able to carry out creative and innovative learning by utilizing technology. One learning approach that is in line with these demands is the STEM (Science, Technology, Engineering and Mathematics) approach. However, this approach is still quite foreign to most teachers and prospective students in the Riau Islands Province. The community service activity aimed at introducing the STEM approach to the people of Riau Islands Province was attended by 120 participants consisting of high school teachers as the main target, prospective teacher students and high school students. This introduction activity begins with the presentation of the STEM approach material, followed by a discussion and question and answer session and ends with an evaluation of the implementation of the activity through filling out a questionnaire. The results of the evaluation of these activities showed that $93.75 \%$ of the participants stated the topics presented were interesting and aroused the curiosity of the participants, so that there was an increase in participants' insights and knowledge about the STEM approach.
\end{abstract}

Keywords: STEM; industrial revolution 4.0

\section{Pendahuluan}

Implementasi Kurikulum 2013 membawa beberapa perubahan paradigma proses pembelajaran, sebagaimana dijelaskan pada Peraturan Menteri Pendidikan dan Kebudayaan Nomor 22 Tahun 2016 tentang Standar Proses. Di mana dalam proses pembelajaran, siswa harus mencari tahu bukan diberi tahu; guru tidak menjadi satu-satunya sumber belajar; pembelajaran tidak lagi berbasis konten tetapi berbasis kompetensi; proses pembelajaran menggunakan pendekatan ilmiah; pembelajaran tidak secara parsial tetapi dilaksanakan secara 


\section{JURNAL ANUGERAH, Desember 2019; I(2): 83-89 e-ISSN 2715-8179}

terpadu; adanya peningkatan dan keseimbangan antara hardskills dan softskills; pembelajaran memperioritaskan pembudayaan dan pemberdayaan siswa sebagai pebelajar sepanjang hayat; pembelajaran menerapkan nilai-nilai melalui keteladanan, menumbuhkan keinginan, dan mengembangkan kreativitas siswa pada proses pembelajaran; pembelajaran dapat dilakukan di mana saja, seperti di rumah, sekolah atau di masyarakat; dan pemanfaatan teknologi informasi dan komunikasi pada pembelajaran untuk meningkatkan ke-efisienan dan efektifitas pembelajaran (Kemendikbud, 2016).

Perubahan paradigma proses pembelajaran tersebut menuntut guru untuk mampu merancang pembelajaran yang kreatif dan inovatif dengan memanfaatkan teknologi yang sejalan dengan Era Revolusi Industri 4.0. Aktivitas pembelajaran dirancang sedemikian rupa sehingga mampu memfasilitasi siswa mengonstruk pengetahuan sendiri dan mengaplikasinya, melatih keterampilan, serta memperluas pengetahuan yang diperolehnya selama pembelajaran.

Pendekatan STEM merupakan salah satu inovasi pembelajaran yang berkembang di Era Revolusi Industri 4.0. STEM merupakan singkatan dari Science, Technology, Engineering dan Mathematics. Pembelajaran dengan pendekatan STEM diidentifikasikan sebagai pembelajaran yang menggabungkan empat disiplin ilmu yaitu Science, Teknologi, Engineering dan Mathematics dengan memfokuskan proses pembelajaran yang mengeksplorasi dua atau lebih bidang yang melibatkan siswa aktif dalam konteks pemecahan masalah dalam dunia nyata (Sanders, 2009 ; Roberts, 2012 ; Bybee, 2013). Lebih jauh, Roberts dan Bybee menyatakan bahwa ke-empat disiplin ilmu yang terintegrasi dalam STEM tersebut harus menjadi satu kesatuan yang holistik.

Tujuan pembelajaran dengan pendekatan STEM yaitu agar siswa memiliki literasi sains dan teknologi yang terlihat dari kemampuannya membaca, menulis, mengamati, dan melakukan sains, serta mampu mengembangkan kemampuan tersebut untuk diterapkan dalam menyelesaikan permasalahan kehidupan sehari-hari terkait bidang ilmu STEM (Bybee, 2013). Dalam konteks pendidikan dasar dan menengah, Pendidikan STEM memiliki tujuan mengembangkan siswa yang paham akan STEM (Bybee, 2013), yang mempunyai: 1 . Pengetahuan, sikap, dan keterampilan dalam memecahkan masalah dunia nyata, mendesain, menjelaskan fenomena alam, dan menyimpulkan berdasar bukti yang ada mengenai STEM; 2 . Memahami karakteristik STEM sebagai penyelidikan, pengetahuan, serta desain yang dikemukakan; 3. Lingkungan material, intelektual dan kultural dibentuk akan kesadaran terhadap disiplin STEM; 4. Keterlibatan dalam kajian STEM sebagai warga negara yang peduli, konstruktif, dan reflektif yang menggunakan ide-ide sains, teknologi, engineering dan matematika.

STEM merupakan pendekatan pembelajaran yang diyakini sejalan dengan ruh Kurikulum 2013. Implemetasi STEM pada pembelajaran di sekolah-sekolah Indonesia dimaksudkan untuk menyiapkan siswa Indonesia dalam memperoleh keterampilan abad 21, yaitu keterampilan berpikir kritis, kreatif dan inovatif, mampu memecahkan masalah dan mengambil keputusan, serta mampu berkomunikasi dan berkolaborasi. Penerapan STEM dalam pembelajaran harus menekankan beberapa aspek yaitu: (1) mengajukan pertanyaan dan mejelaskan masalah; (2) mengembangkan dan menggunakan model; (3) merancang dan melaksanaan penelitian, (4) menginterpretasi dan menganalisis data; (5) menggunakan pemikiran matematika dan komputasi, (6) membuat penjelasan dan merancang solusi; (7) Berpartisipasi dalam kegiatan argumentasi yang didasarkan pada bukti yang ada (8) mendapatkan informasi, memberikan evaluasi dan menyampaikan informasi (National Research Council, 2012).

Meskipun pendekatan STEM sejalan dengan Kurikulum 2013, namun pendekatan ini masih terbilang asing bagi kebanyakan guru maupun mahasiswa calon guru di Provinsi Kepulauan Riau. Hal ini menjadi perhatian bagi dosen Program Studi Pendidikan Matematika FKIP Universitas Maritim Raja Ali Haji (UMRAH). Sehingga tim dosen Prodi Pendidikan Matematika FKIP UMRAH merasa perlu mengadakan kegiatan Pengabdian Kepada Masyarakat Mandiri (PKMM) dengan judul "Pengenalan Pendekatan STEM sebagai Inovasi Pembelajaran Era Revolusi Industri 4.0”. 
Kegiatan ini bertujuan untuk memperkenalkan pendekatan STEM kepada masyarakat dalam hal ini adalah guru SMA sebagai sasaran utama, mahasiswa calon guru serta siswa SMA di Provinsi Kepulauan Riau. Kegiatan ini diharapkan dapat memberikan dampak pada perbaikan proses pembelajaran di kelas. Melalui kegiatan pengabdian ini, peserta mendapatkan wawasan tentang pendekatan STEM dan rancangan pembelajaran dengan pendekatan STEM. Adapun dalam merancangan pembelajaran dengan pendekatan STEM, peserta dapat mengikuti beberapa langkah berikut: 1) Melakukan analisis Kompetensi Dasar (KD). Analisis KD dimaksudkan untuk mengidentifikasi KD 3 dan KD 4 yang mengandung muatan STEM sehingga berpotensi untuk dibelajarkan menggunakan pendekatan STEM. Hal ini perlu dilakukan karena tidak semua KD mengandung muatan STEM. 2) Mengidentifikasi topik yang sesuai dengan KD, yaitu topik yang mengandung muatan STEM sehingga dapat dibelajarkan melalui pendekatan STEM. 3) Merumuskan indikator pencapaian kompetensi. 4) Melakukan analisis materi STEM, kemudian mendeskripsikan materi STEM yang dikandung oleh KD 3 dan KD 4. Deskripsi muatan STEM dapat dilihat pada tabel 1.

Tabel 1.

Deskripsi Muatan STEM

\begin{tabular}{lll}
\hline No & Muatan STEM & \multicolumn{1}{c}{ Deskripsi } \\
\hline 1 & Science & $\begin{array}{l}\text { Berupa fakta, konsep, prosedural tentang sains yang terkandung dalam KD yang } \\
\text { akan dipelajari }\end{array}$ \\
\hline 2 & Technology & Berupa teknologi yang digunakan dan atau dikembangkan \\
\hline 3 & Engineering & $\begin{array}{l}\text { Aktivitas perekayasaan: produk apa yang dirancang, alat dan bahan yang } \\
\text { diperlukan, menguji coba keoptimalan produk, evaluasi hasil produk, dll. }\end{array}$ \\
\hline 4 & Mathematic & $\begin{array}{l}\text { Aktivitas matematika yang diperlukan dalam perhitungan, seperti: konsep } \\
\text { matematika yang diterapkan, teorema/rumus yang diperlukan. }\end{array}$ \\
\hline
\end{tabular}

Langkah ke-5 adalah merancang Rencana Pelaksanaan Pembelajaran (RPP). Rencana pelaksanaan pembelajaran ini dirancang berdasarkan aturan yang berlaku sebagaimana ditetapkan pada standar proses. Penerapan Pendekatan STEM dapat dikombinasikan dengan model pembelajaran PjBL (Project Based Learning) atau PBL (Problem Based Learning). Karena itu, sintak pembelajarannya mengikuti model pembelajaran yang dipilih dan diintegrasikan dengan STEM. Pembelajaran dapat berlangsung beberapa kali pertemuan, tergantung pada keluasan atau kedalaman materi pada KD 3 dan KD 4.

Selain itu, peserta juga diperkenalkan dengan teknik dan bentuk instrumen penilaian serta rubrik penilaian siswa untuk tugas proyek. Kegiatan pengabdian ini dilaksanakan dalam satu kali pertemuan.

\section{Metode}

Kegiatan pengabdian masyarakat mandiri (PKMM) ini dilaksanakan pada hari Sabtu tanggal 16 November 2019. Pelaksanaan kegiatan diadakan di Aula Bulang Linggi Dinas Perpustakaan dan Arsip Tanjungpinang. Sasaran kegiatan adalah guru SMA sebagai sasaran utama, mahasiswa calon guru serta siswa SMA yang berasal dari Provinsi Kepulauan Riau. Total khalayak sasaran kegiatan adalah 120 orang.

Bentuk kegiatan pengabdian masyarakat yang dilaksanakan berupa Pengenalan Pendekatan STEM sebagai Inovasi Pembelajaran Era Revolusi Industri 4.0. Pelaksanaan kegiatan diawali dengan pemaparan materi tentang pendekatan STEM, desain pembelajaran STEM dan evaluasi pembelajaran dengan pendekatan STEM. Selanjutnya, diadakan sesi diskusi dan tanya jawab antar peserta dan pemateri.

Pada akhir kegiatan pengabdian kepada masyarakat ini dilakukan evaluasi terhadap pelaksanaan kegiatan. Evaluasi kegiatan bertujuan untuk mengetahui tingkat pemahaman peserta terkait materi yang dipaparkan dan kebermanfaatan kegiatan pengabdian masyarakat yang telah dilakukan. Instrumen evaluasi yang digunakan berupa angket tertutup melalui tautan pada google form. 
JURNAL ANUGERAH, Desember 2019; I(2): 83-89

e-ISSN 2715-8179

\section{Hasil dan Pembahasan}

Kegiatan pengabdian kepada masyarakat dengan judul Pengenalan Pendekatan STEM sebagai Suatu Inovasi Pembelajaran Era Revolusi Industri 4.0 dihadiri oleh 120 orang peserta yang terdiri dari guru SMA sebagai sasaran utama dan siswa SMA di Provinsi Kepulauan Riau, serta mahasiswa calon guru Universitas Maritim Raja Ali Haji. Implementasi kegiatan sesuai dengan jadwal yang telah ditetapkan yaitu pada tanggal 16 November 2019. Kegiatan pengabdian kepada masyarakat ini telah terlaksana dengan baik dan lancar.

Adapun kegiatan yang telah dilakukan berupa pemaparan materi untuk menambah pengetahuan dan wawasan peserta tentang pendekatan STEM. Materi yang dipaparkan dibagi atas tiga bagian yaitu penjelasan tentang pendekatan STEM, desain pembelajaran STEM dan evaluasi pembelajaran dengan pendekatan STEM. Bentuk evaluasi pembelajaran yang diperkenalkan berupa rubrik penilaian kinerja siswa setelah belajar dengan pendekatan STEM. Selain pemaparan materi, juga diadakan sesi diskusi dan tanya jawab untuk mempertajam pemahaman peserta. Gambar 1 menyajikan kegiatan pemaparan materi.

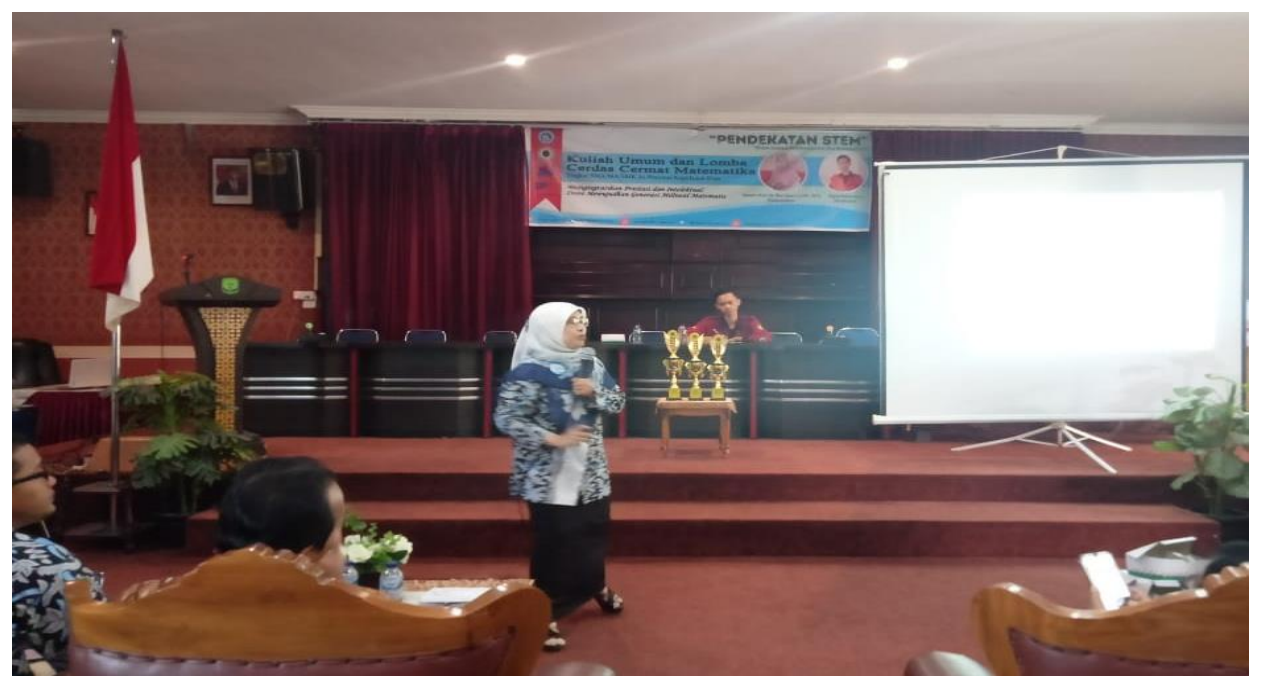

Gambar 1. Pemaparan materi pendekatan STEM

Kegiatan diakhiri dengan evaluasi. Teknik evaluasi melalui angket yang terdiri dari 5 item. Peserta diminta untuk mengisi angket secara online melalui tautan google form. Tim pelaksana pengabdian menginformasikan tautan google form yang dapat digunakan untuk masuk ke laman angket, kemudian memberikan instruksi dan arahan tentang tata cara pengisian angket. Peserta tampak antusias dengan metode pengumpulan data melalui pemanfaatan teknologi google form menggunakan ponsel masing-masing. Gambar 3 menampilkan kegiatan evaluasi tersebut. 


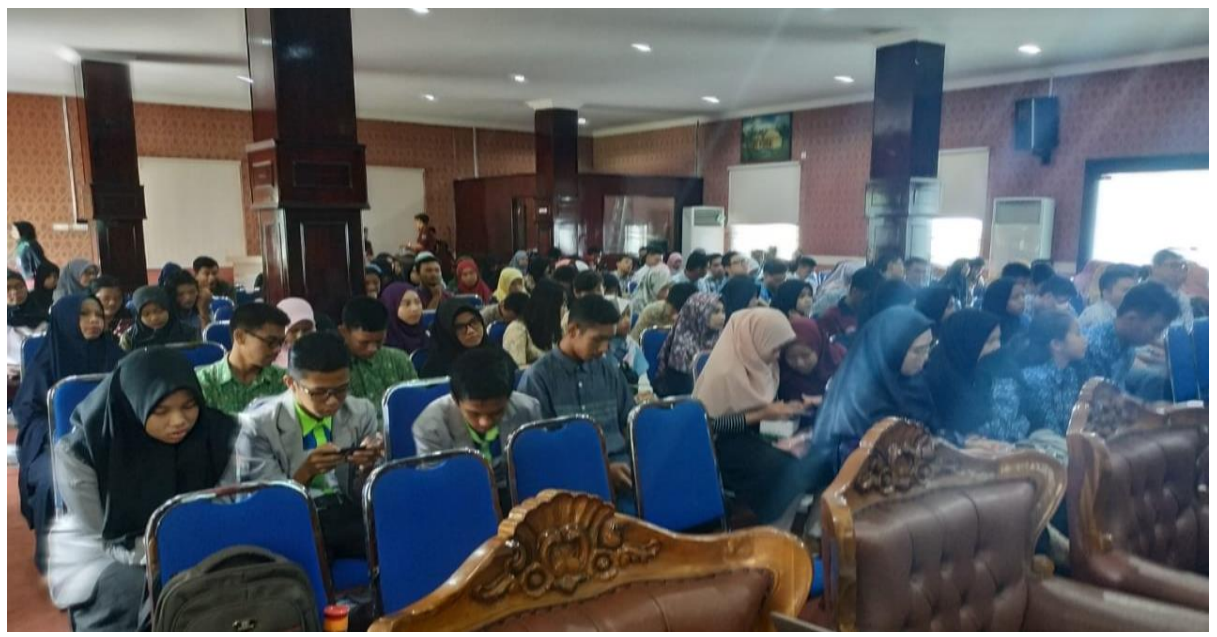

Gambar 2. Pengisian angket melalui tautan Google Form

Data hasil pengisian angket evaluasi pelaksanaan kegiatan pengabdian ini, disajikan pada Gambar 4. Sebanyak $93,75 \%$ peserta menyatakan bahwa topik yang disajikan menarik dan menggugah rasa ingin tahu mereka (item 1). Hasil ini memperkuat pernyataan Shernoff, dkk (Shernoff, Sinha, Bressler, \& Ginsburg, 2017) bahwa STEM merupakan salah satu pendekatan pembelajaran yang mampu menjadi pusat perhatian masyarakat di lingkungan dunia pendidikan khususnya guru dan dosen.

\section{DATA HASIL ANGKET EVALUASI PKM}

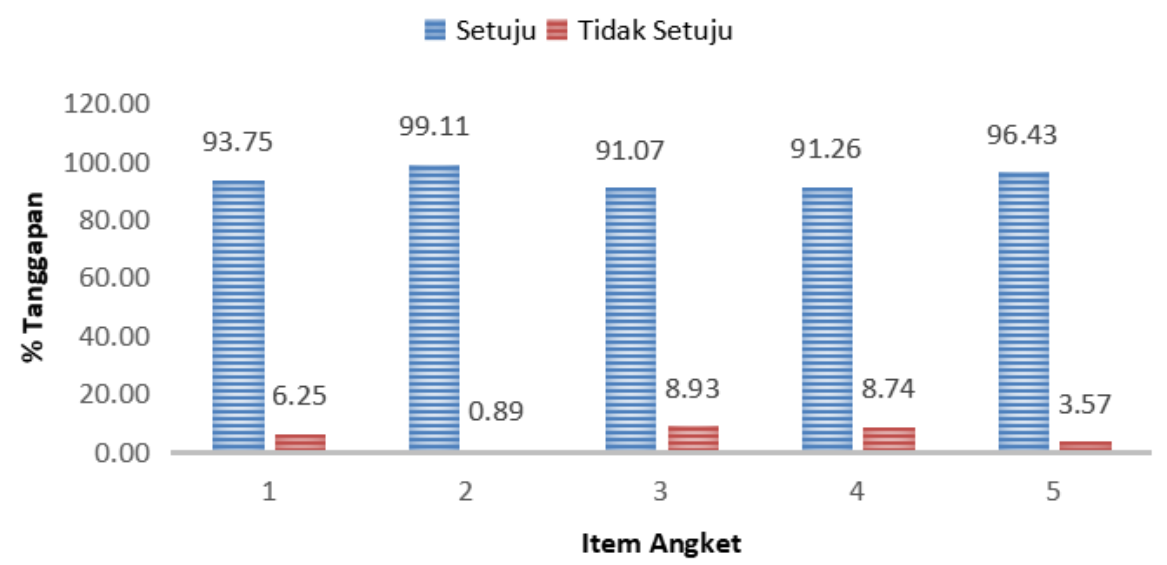

Gambar 3. Respon peserta terhadap pelaksanaan kegiatan pengabdian kepada masyarakat

Sebanyak 99,11\% peserta menyatakan bahwa adanya penambahan wawasan dan pengetahuan mereka tentang pendekatan STEM (item 2) dan 91,07\% peserta menyatakan memiliki pemahaman yang lebih baik tentang penyusunan rencana pelaksanaan pembelajaran dengan menggunakan pendekatan STEM (item 3). Hal ini menunjukkan bahwa kegiatan pengabdian masyarakat yang telah dilaksanakan secara nyata memberikan wawasan dan pengetahuan tentang Pendekatan STEM kepada masyarakat di Provinsi Kepulauan Riau.

Selanjutnya, hasil angket pada Gambar 3 juga menunjukkan bahwa 91,26\% peserta yang terdiri dari unsur dosen, guru dan mahasiswa termotivasi untuk menerapkan STEM pada kegiatan pembelajaran (item 4). Hal ini menunjukkan bahwa kegiatan pengabdian masyarakat yang telah dilaksanakan memberikan manfaat positif bagi peserta yaitu perubahan motivasi berupa semangat berkarya untuk menyajikan kegiatan 


\section{JURNAL ANUGERAH, Desember 2019; I(2): 83-89 e-ISSN 2715-8179}

belajar-mengajar yang lebih baik bagi peserta didik. Sebanyak 96,43\% peserta memiliki keyakinan bahwa penerapan STEM pada pembelajaran dapat melatih kemampuan siswa dalam berpikir kritis, kreatif dan inovatif (item 5). STEM merupakan pembelajaran yang menggunakan pendekatan berpusat pada siswa (Thibaut et al., 2018); (Ejiwale, 2012). Hasil studi menunjukkan bahwa pembelajaran dengan berpusat pada siswa dapat meningkatkan keterampilan proses yang dimiliki siswa seperti kemampuan berpikir kritis (Siregar, Deniyanti, \& Hakim, 2018). STEM mengakomodasi perkembangan teknologi untuk menciptakan kegiatan dan lingkungan belajar yang produktif, kreatif dan inovatif. Hal tersebut memberikan kontribusi positif pada perkembangan kemampuan siswa dalam berpikir kritis, kemampuan bekerjasama, kemampuan berkomunikasi dan pemecahan masalah, serta kemampuan lain yang relevan terhadap kebutuhan abad 21 (Stehle \& Peters-Burton, 2019).

Hasil evaluasi kegiatan PkMM menunjukkan bahwa kegiatan PkMM yang telah dilaksanakan memberikan manfaat yang besar terhadap peserta. Salah satu manfaat yang didapat oleh peserta adalah terjadinya penambahan wawasan dan pengetahuan peserta terhadap materi yang disajikan. Hal ini dikarenakan Pendekatan STEM merupakan pendekatan yang tergolong baru dan menjadi pembicaraan oleh banyak kalangan pendidik, sehingga dapat dipahami adanya daya tarik tersendiri bagi peserta untuk mengikuti kegiatan PkMM yang mengangkat materi tentang pendekatan STEM. Maka, merupakan sesuatu yang wajar jika hampir semua peserta menyatakan dapat meraih manfaat yang besar.

\section{Kesimpulan}

Berdasarkan hasil evaluasi dapat disimpulkan bahwa target PkMM tercapai dengan baik yaitu terjadi penambahan wawasan dan pengetahuan tentang pendekatan STEM, mendesain pembelajaran dengan pendekatan STEM dan langkah-langkah perencanaan pembelajaran dengan pendekatan STEM. Kegiatan pengabdian kepada masyarakat dengan judul pendekatan STEM sebagai suatu inovasi pembelajaran era revolusi industri 4.0 berjalan lancar. Kegiatan ini mendapat sambutan yang sangat baik oleh peserta, ditunjukkan dengan tingkat kehadiran peserta yang tinggi, partisipasi aktif dalam kegiatan diskusi dan tanya jawab, serta tidak terdapat peserta yang meninggalkan ruangan sebelum kegiatan pengabdian masyarakat berakhir.

\section{Saran}

Mencermati capaian dari kegiatan pengabdian kepada masyarakat ini, kiranya perlu diadakan kegiatan lanjutan berupa workshop tentang implemetasi STEM pada pembelajaran, sehingga guru mampu merancang dan melaksanakan pembelajaran dengan pendekatan STEM.

\section{Ucapan Terimakasih}

Terima kasih kepada Prodi Pendidikan Matematika dan Himpunan Mahasiswa Matematika UMRAH yang telah memberi dukungan moral bagi terlaksananya kegiatan pengabdian kepada masyarakat ini.

\section{Referensi}

Bybee, R. W. (2013). The Case for STEM Education: Challenges and Opportunities. NTSA press.

Ejiwale, J. A. (2012). Facilitating teaching and learning across STEM fields. Journal of STEM Education: Innovations and Research.

Kemendikbud. (2016). Salinan Lampiran Peraturan Menteri Pendidikan Dan Kebudayaan Nomor 22 Tahun 2016 Tentang Standar Proses Pendidikan Dasar Dan Menengah. PERMENDIKBUD. https://doi.org/https://doi.org/10.3929/ethz-b-000238666

National Research Council. (2012). A Framework for K-12 Science Education: Practices, Crosscutting concepts, and core ideas. Washington DC: National Academies Press. 
Roberts, A. (2012). A Justification for STEM Education. Technology and Engineering Teachere. https://doi.org/10.1126/science.1201783

Sanders, M. (2009). STEM, STEM education, STEM mania. The Technology Teacher.

Shernoff, D. J., Sinha, S., Bressler, D. M., \& Ginsburg, L. (2017). Assessing teacher education and professional development needs for the implementation of integrated approaches to STEM education. International Journal of STEM Education. https://doi.org/10.1186/s40594-017-0068-1

Siregar, N. A. R., Deniyanti, P., \& Hakim, L. El. (2018). Pengaruh model pembelajaran core terhadap kemampuan berpikir kritis dan disposisi matematis ditinjau dari kemampuan awal matematika siswa SMA Negeri di Jakarta Timur. Jurnal Penelitian dan Pembelajaran Matematika. https://doi.org/10.30870/jppm.v11i1.2997

Stehle, S. M., \& Peters-Burton, E. E. (2019). Developing student 21 st Century skills in selected exemplary inclusive STEM high schools. International Journal of STEM Education, 6(1), 39. https://doi.org/10.1186/s40594-019-0192-1

Thibaut, L., Ceuppens, S., De Loof, H., De Meester, J., Goovaerts, L., Struyf, A., ... Depaepe, F. (2018). Integrated STEM Education: a systematic review of instructional practices in secondary education. European Journal of STEM Education. https://doi.org/10.20897/ejsteme/85525 